\title{
Postharvest Infiltration of Polyamines and Calcium Influences Ethylene Production and Texture Changes in 'Golden Delicious' Apples
}

\author{
Chien Yi Wang ${ }^{1}$, William S. Conway ${ }^{2}$, Judith A. Abbott ${ }^{3}$, and George F. Kramer ${ }^{4}$ \\ Beltsville Agricultural Research Center, Agricultural Research Service, U.S. Department of Agriculture, \\ Beltsville, MD 20705-2350 \\ Carl E. Sams ${ }^{5}$ \\ Department of Plant and Soil Science, University of Tennessee, Knoxville, TN 37901-1071
}

Additional index words. Malus domestica, putrescine, spermidine, storage, quality, firmness

\begin{abstract}
Prestorage infiltration of 'Golden Delicious' apples (Malus domestica Borkh.) with calcium (Ca) retarded texture changes during storage at $\mathrm{OC}$ and inhibited ethylene production of the fruit at $20 \mathrm{C}$. Infiltration of the fruit with the polyamines (PA) putrescine (PUT) or spermidine (SPD) also altered texture changes, but did not inhibit ethylene production. When the fruit were treated with $\mathrm{Ca}$ first and then with PA, cell wall-hound Ca concentrations increased 4-fold, but PA levels in the cell wall increased only slightly. When the fruit were treated with PA first and then with Ca, PA levels in the cell wall increased 3-fold, but Ca concentration increased only 2-fold. These results indicate that Ca and PA may he competing for the same binding sites in the cell wall and that the improvement of fruit quality during storage by these cations could involve strengthening of the cell wall.
\end{abstract}

Considerable evidence has shown that polyamines actively regulate plant growth, development, and senescence (Slocum and Flores, 1991). Polyamines are ubiquitous in plant cells and their concentrations fluctuate in response to environmental changes such as light and temperature (Galston, 1983). Dramatic changes in the polyamine content of plant tissues have been reported under various kinds of stresses (Flores et al., 1985). Polyamines can affect DNA and RNA synthesis and degradation; regulate rates of transcription; inhibit activities of protease, ribonuclease, peroxidase, and polygalacturonase; stabilize ribosomal structure; and maintain membrane integrity (Smith, 1990). Application of polyamines prevented lysis of isolated protoplasts and reduced the breakdown of macromolecules (Altman et al., 1977). Exogenous polyamines also delayed senescence in excised leaves and leaf segments of some monocots and dicots (Kaur-Sawhney and Galston, 1979). Further, postharvest treatments that delayed senescence of apples, such as low $\mathrm{O}_{2}$ storage, also maintained high levels of polyamines in the fruit tissue (Kramer et al., 1989). Exogenous applications of polyamines retarded softening of 'Golden Delicious' and 'McIntosh' apples (Kramer et al., 1991). The potential of using polyamines for maintaining postharvest quality of fruits deserves further investigation.

High $\mathrm{Ca}$ content in fruit tissues has been shown to reduce disorders (Sharples and Johnson, 1977), retard softening (Mason et al., 1975), and inhibit decay (Conway et al., 1991). In addition to strengthening cell walls and membranes, $\mathrm{Ca}$ also regulates some physiological processes that may directly or indirectly affect the

Received for publication 14 Sept. 1992. Accepted for publication 25 Mar. 1993. We express our appreciation to Andrew Bartoszyk, William Beavers, George Brown, and Hilarine Repace for valuable technical assistance. Use of a company or product name by the USDA does not imply approval or recommendation of the product to the exclusion of others which may also be suitable. The cost of publishing this paper was defrayed in part by the payment of page charges. Under postal regulations, this paper therefore must be hereby marked advertisement solely to indicate this fact. ${ }^{1}$ Research Horticulturist, Horticultural Crops Quality Laboratory.

${ }^{2}$ Research Plant Pathologist, Horticultural Crops Quality Laboratory.

${ }^{3}$ Research Horticulturist, Instrumentation and Sensing Laboratory.

${ }^{4}$ Research Associate, Climate Stress Laboratory.

${ }^{5}$ Associate Professor. quality of fruits (Poovaiah, 1988). Because both $\mathrm{Ca}$ and polyamines are cations and have similar beneficial effects in improving fruit quality, the objective of this study was to compare the effects of these substances on fruit firmness, to determine if they may be competing for the same binding site in the cell wall, and to ascertain if additive effects could be obtained from combined treatments of these cations.

\section{Materials and Methods}

\section{Plant material}

'Golden Delicious' apples were harvested from mature trees in a commercial orchard in south-central Pennsylvania. The fruit were picked at the mature but preclimacteric stage, as indicated by $\mathrm{CO}_{2}$ and ethylene production rates of samples selected at random.

\section{Treatment and sampling}

The apples were randomized and divided into eight lots for the following treatments: 1) control (distilled $\mathrm{H}_{2} \mathrm{O}$ ); 2) $10 \mathrm{~mm}$ PUT; 3) $0.5 \mathrm{~mm} \mathrm{SPD}$; 4) $3 \% \mathrm{Ca}\left(\mathrm{CaCl}_{2} \cdot 2 \mathrm{H}_{2} \mathrm{O}\right)$; 5) $10 \mathrm{~mm}$ PUT followed by $3 \% \mathrm{Ca}$; 6) $0.5 \mathrm{~mm}$ SPD followed by $3 \% \mathrm{Ca}$; 7 ) $3 \% \mathrm{Ca}$ followed by $10 \mathrm{~mm}$ PUT; 8) 3\% Ca followed by $0.5 \mathrm{~mm}$ SPD. A pressure of 103 $\mathrm{kPa}$ for 3 min was used for the infiltration of these chemicals. Control fruit were treated similarly with distilled water. Two hundred fruit were used in each treatment. Following infiltration, the fruit were placed on Kraft paper and allowed to dry before storage at $0 \mathrm{C}$ in multiperforated polyethylene bags. Samples were taken at harvest and at 4-week intervals during storage for measurements of texture and for cell wall extractions for determinations of $\mathrm{Ca}$ and polyamines.

\section{Measurement of ethylene production}

Following chemical infiltration, a subset of fruit from all treatments was placed at $20 \mathrm{C}$ for 10 days to evaluate the effect of chemicals on ethylene production. A compact automatic system (Watada and Massie, 1981) consisting of a Hewlett-Packard 5890 gas chromatograph (Hewlett-Packard, Rockvilie, Md.) equipped 
with a Porapak-Q column and a flame ionization detector was used for ethylene measurement.

\section{Texture measurements}

Magness-Taylor (MT) firmness was recorded using a standard 11.1-mm Magness-Taylor probe mounted on an Instron Universal Testing Machine (Instron, Canton, Mass.) interfaced to a personal computer (Abbott et al., 1982, 1984). Measurements were made on two opposite manually pared sites; a beveled holder prevented bruising of the opposite side. The Instron was programmed to travel at $127 \mathrm{~mm} \cdot \mathrm{min}^{-1}$ for $7.9 \mathrm{~mm}$ after contact with the flesh. Complete force vs. deformation (F/D) curves were recorded by the computer and analyzed later for maximum forces and other force, slope, distance, and area characteristics (Abbott et al., 1984).

Tissue compression tests (Abbott et al., 1984) also were made on the same fruit. Two radial cylinders of apple flesh were removed at $90^{\circ}$ to the MT sites using a $15-\mathrm{mm}$-diameter cork borer. A 2.5 $\mathrm{mm}$ slice including the skin was discarded and the next $10-\mathrm{mm}$ segment was compressed between flat plates at $127 \mathrm{~mm} \cdot \mathrm{min}^{-1}$. The Instron was programmed to travel $7.5 \mathrm{~mm}$ after contact with the specimen, reverse, and continue upward for another $2.5 \mathrm{~mm}$, collecting data throughout. Compression F/D curves were recorded and analyzed as described for MT.

The forces reported are FMAX, maximum force required to penetrate or compress the flesh; FFRC, force at the first peak or at initial flesh failure; and FFUL, force at maximum penetration or compression. The slope reported, M@05, is slope at $0.05-\mathrm{mm}$ penetration or compression. Analyses of slopes at other locations before FFRC showed similar results, so the data are not reported. Interpretation of MT and compression F/D curves has not been fully established. In the MT using F/D curves, FMAX is simply the maximum force required to move the probe $7.9 \mathrm{~mm}$ and is comparable to the usual single force value read from MT firmness tests. FMAX may occur at FFRC, FFUL, or at a peak between them. FMAX is interpreted similarly for compression curves. Height of the first peak, FFRC, measures force to fracture or the force that causes major failure of the tissue. FFRC and sharpness of the fracture peak are thought by Abbott (1984) to be related to crispness and mealiness. Slope of the curve before major tissue failure at FFRC (M@05) is a measure of stiffness; decreasing slopes indicate shifts from rigid to elastic.

\section{Cell wall extraction}

The peel and outer flesh of the fruit were removed to a depth of $2 \mathrm{~mm}$ with a mechanical peeler and discarded. The next $5 \mathrm{~mm}$ of cortical tissue were then removed from the entire fruit and used for cell wall extraction. Each sample was composed of flesh from five apples and three samples from each treatment were analyzed. About $100 \mathrm{~g}$ of tissue was placed immediately in $100 \mathrm{ml}$ of cold $80 \%$ ethanol and stored at $-80 \mathrm{C}$. The tissue samples were homogenized subsequently in a Waring blender. The homogenate was filtered through two layers of Miracloth and the residue was washed with $50 \mathrm{ml}$ of $80 \%$ ethanol. The washed residue was used for cell wall extraction following a modification of the procedures described by Tong and Gross (1990). The washed residue was suspended in $100 \mathrm{ml}$ of $80 \%$ ethanol and heated in a boiling water bath for $5 \mathrm{~min}$, stirred to break up aggregates, and filtered through Miracloth. The residue was rinsed with deionized water, sus-

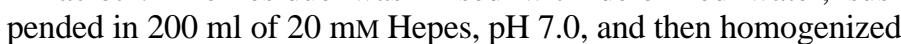
with a Polytron (Brinkmann Instruments, Westbury, N.Y.) for 1 min. The resulting homogenate was filtered through Miracloth, and the residue rinsed with Hepes buffer. The residue was suspended in $100 \mathrm{ml}$ of Hepes buffer and placed inside a pressure bomb under $13,790 \mathrm{kPa}$ of pressure for $10 \mathrm{~min}$. The suspension then was extracted sequentially with $100 \mathrm{ml}$ phenol/Tris $\mathrm{pH} 7.5$ (Huber, 1991), $200 \mathrm{ml} 1$ chloroform : 1 methanol (v/v) and acetone by suspending the residue in the respective solvents, stirring for 60 min (phenol/Tris extraction) or $10 \mathrm{~min}$ (chloroform : methanol and acetone extractions). The residue was washed with deionized water (phenol/Tris extraction), and passed through a sintered-glass

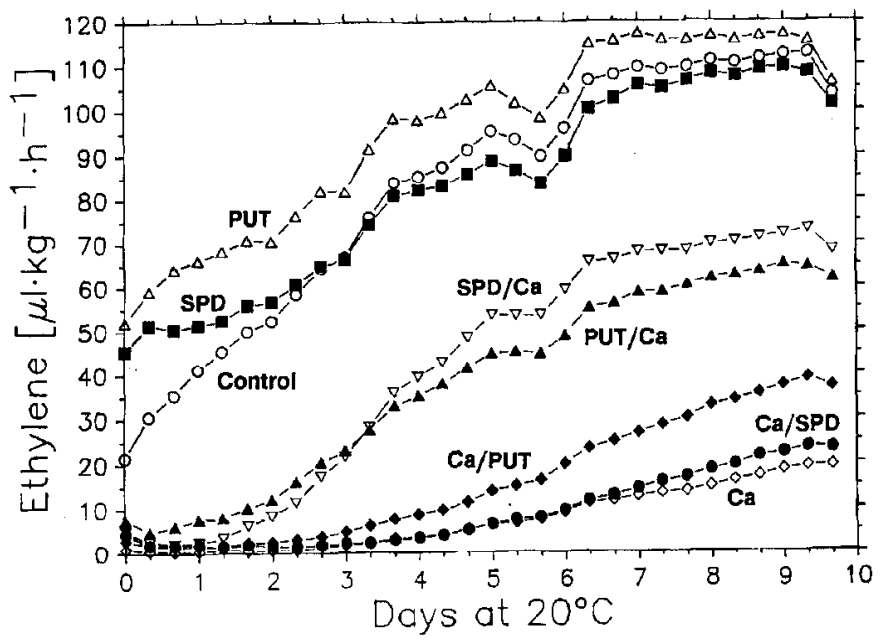

Fig. 1. Ethylene production of 'Golden Delicious' apples after the treatments with $10 \mathrm{~mm}$ PUT, $0.5 \mathrm{~mm} \mathrm{SPD}, 3 \% \mathrm{Ca}, 10 \mathrm{~mm}$ PUT followed by $3 \% \mathrm{Ca}, 0.5 \mathrm{~mm}$ SPD followed by $3 \% \mathrm{Ca}, 3 \% \mathrm{Ca}$ followed by $10 \mathrm{~mm}$ PUT, or $3 \% \mathrm{Ca}$ followed by 0.5 mM SPD.
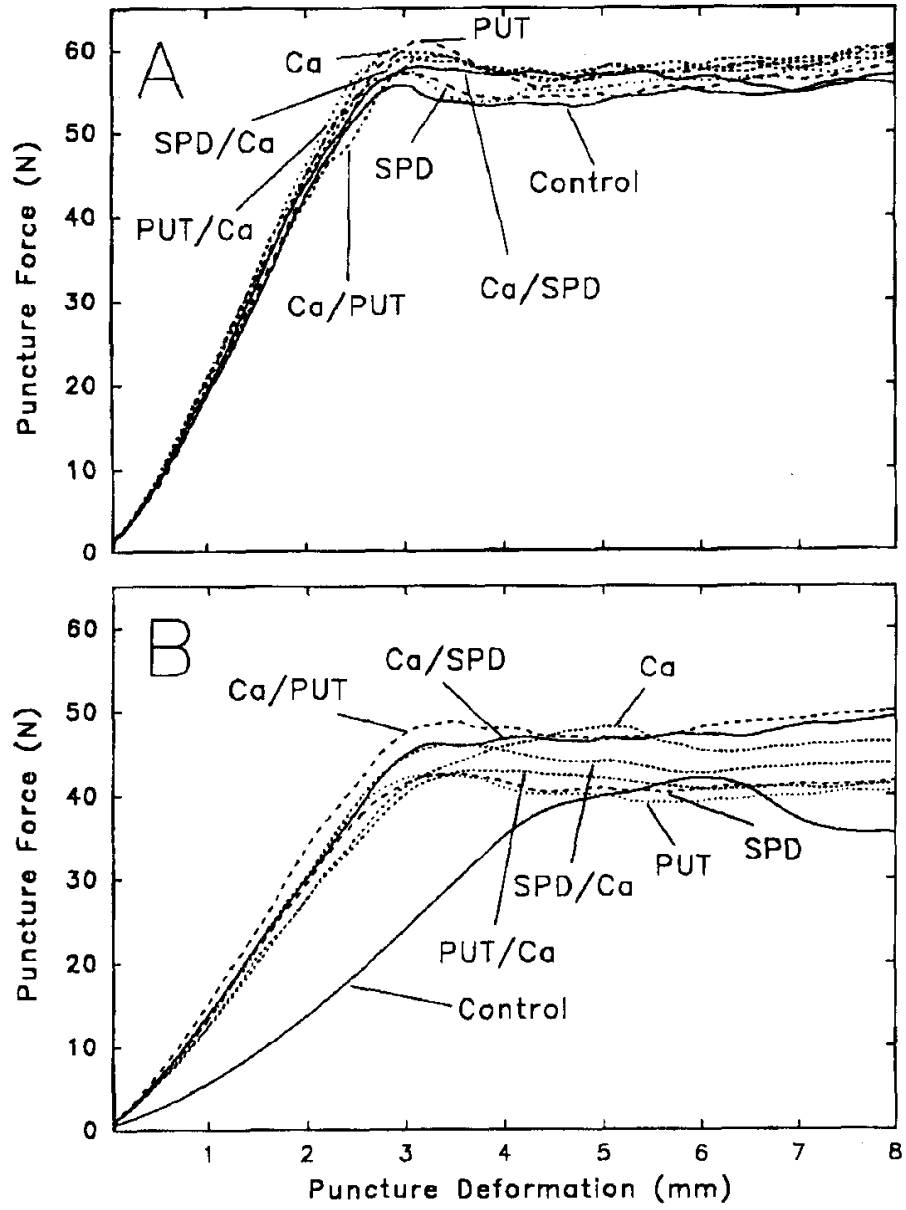

Fig. 2. Magness-Taylor force versus deformation curves for 'Golden Delicious apples after chemical treatment: (A) Before storage and (B) after 24 weeks of storage at $0 \mathrm{C}$. See Fig. 1 for concentrations used. 
filter. The wall material was air-dried overnight, followed by drying in vacuo over $\mathrm{P}_{2} \mathrm{O}_{5}$ at $40 \mathrm{C}$ for $48 \mathrm{~h}$.

\section{Calcium determination}

Cell wall samples $(125 \mathrm{mg})$ were ashed at $500 \mathrm{C}$ for $15 \mathrm{~h}$ and the residue was dissolved in $5 \mathrm{ml}$ of $2 \mathrm{~N} \mathrm{HCl}$ and analyzed for $\mathrm{Ca}$ content with a Thermo-Jarrell Ash Model 61 Inductively Coupled Argon Plasma (ICAP) Atomic Emission Spectrometer (AES, Franklin, Mass.). Three replications, each consisting of cell walls derived from five fruit, were analyzed for each treatment.

\section{Polyamine analysis}

Polyamines in the cell wall fraction were analyzed after hydrolysis of wall material. Twenty milligrams of cell wall material was hydrolyzed with $2 \mathrm{ml} 2 \mathrm{~N}$ trifluoroacetic acid at 100C for $2 \mathrm{~h}$. The extracts were evaporated to dryness under $\mathrm{N}_{2}$ and redissolved in $5 \% \mathrm{HClO}_{4}$. Polyamines in the $\mathrm{HClO}_{4}$ extracts were determined by dansylation and HPLC separation similar to the method reported for samples from fresh tissues (Kramer et al., 1989).

\section{Results}

\section{Ethylene production}

Ethylene production resulting from the various treatments could be classified into three distinct groups (Fig. 1). In the first, ethylene production was not affected by the treatment; this group consisted of treatments with only PUT and SPD. In the second group, ethylene production was inhibited greatly by the treatment; this group consisted of treatment with $\mathrm{Ca}$ only and treatments in which $\mathrm{Ca}$ was the first ion to be applied. In the third group, ethylene production was inhibited moderately by the applied treatment; this group consisted of treatments in which $\mathrm{Ca}$ was applied as the second ion following the infiltration of polyamines.

\section{Texture}

Magness-Taylor. All treatments had similar MT F/D curves before storage (Fig. 2A), indicating that they had similar firmness (Table 1). The slope of the control apples is marginally lower than that of apples treated with PUT. After 24 weeks of storage at 0C (Fig. 2B), the control fruit underwent elastic deformation before the probe penetrated the flesh, so the slope of the mean curve was much lower than those of the other treatments and the probe did not actually penetrate the full $7.9 \mathrm{~mm}$. The only other significant difference in slope indicates that application of $\mathrm{Ca}$ followed by PUT caused somewhat stiffer fruit (higher M@05) than application of $\mathrm{Ca}$ or PUT followed by $\mathrm{Ca}$. Application of $\mathrm{Ca}$ alone resulted in significantly higher force values for the first and second peaks of the MT curve than did application of either polyamine.

In short, after nearly 6 months of storage, apples from the control treatment were noticeably more elastic than those from other treatments and fruit treated with $\mathrm{Ca}$ were harder than those treated with PUT or SPD. There was a trend for application of Ca before PUT to be more effective in maintaining firmness than the reverse treatment.

Table 1. Analysis of variance probability values for the effects of calcium and polyamine infiltration on 'Golden Delicious' apple texture as measured by Magness-Taylor and tissue compression tests. ${ }^{2}$

\begin{tabular}{|c|c|c|c|c|c|c|c|c|c|}
\hline \multirow{2}{*}{$\begin{array}{l}\text { Treatments } \\
\text { contrasted }^{y}\end{array}$} & & \multicolumn{4}{|c|}{ Initial } & \multicolumn{4}{|c|}{24 Weeks } \\
\hline & & FMAX $^{\mathrm{x}}$ & FFRC & FFUL & M@05 & FMAX & FFRC & FFUL & M@05 \\
\hline \multicolumn{10}{|c|}{ Magness-Taylor } \\
\hline \multirow[t]{5}{*}{ Control } & vs. all others & 0.15 & NS & 0.17 & 0.14 & NS & NS & 0.01 & 0.01 \\
\hline & vs. PA alone & NS & NS & NS & 0.08 & NS & NS & 0.14 & 0.01 \\
\hline & vs. PUT alone & 0.16 & 0.20 & 0.18 & 0.02 & NS & NS & NS & 0.01 \\
\hline & vs. SPD alone & NS & NS & NS & NS & NS & NS & 0.16 & 0.01 \\
\hline & vs. Ca alone & 0.12 & NS & NS & NS & NS & NS & 0.02 & 0.01 \\
\hline \multirow[t]{2}{*}{ PA alone } & vs. $\mathrm{PA}+\mathrm{Ca}$ & NS & NS & NS & NS & NS & NS & NS & NS \\
\hline & vs. Ca alone & NS & NS & NS & NS & 0.02 & 0.03 & 0.01 & NS \\
\hline \multirow{3}{*}{$\begin{array}{l}\mathrm{PA}+\mathrm{Ca} \\
\mathrm{Ca} \text { alone }\end{array}$} & vs. $\mathrm{Ca}+\mathrm{PA}$ & NS & NS & NS & 0.13 & 0.09 & 0.18 & 0.02 & NS \\
\hline & vs. $\mathrm{PA}+\mathrm{Ca}$ & NS & NS & NS & NS & NS & NS & NS & 0.16 \\
\hline & vs. $\mathrm{Ca}+\mathrm{PA}$ & NS & NS & NS & 0.04 & NS & NS & NS & 0.02 \\
\hline $\mathrm{PUT}+\mathrm{Ca}$ & vs. Ca + PUT & NS & NS & NS & 0.14 & 0.17 & 0.17 & 0.05 & 0.07 \\
\hline $\mathrm{SPD}+\mathrm{Ca}$ & vs. $\mathrm{Ca}+\mathrm{SPD}$ & NS & NS & NS & NS & NS & NS & 0.20 & NS \\
\hline \multicolumn{10}{|c|}{ Texture profile } \\
\hline \multirow[t]{5}{*}{ Control } & vs. all others & 0.01 & NS & 0.01 & NS & NS & NS & 0.18 & 0.01 \\
\hline & vs. PA alone & 0.03 & NS & 0.02 & NS & NS & NS & NS & 0.01 \\
\hline & vs. PUT alone & 0.03 & NS & 0.02 & NS & NS & NS & NS & 0.01 \\
\hline & vs. SPD alone & NS & NS & 0.09 & NS & NS & NS & NS & 0.01 \\
\hline & vs. Ca alone & 0.01 & NS & 0.01 & NS & NS & 0.07 & 0.15 & 0.01 \\
\hline \multirow[t]{2}{*}{ PA alone } & vs. $\mathrm{PA}+\mathrm{Ca}$ & NS & NS & NS & NS & NS & NS & NS & NS \\
\hline & vs. Ca alone & NS & NS & NS & 0.19 & 0.06 & NS & 0.01 & 0.03 \\
\hline $\mathrm{PA}+\mathrm{Ca}$ & vs. $\mathrm{Ca}+\mathrm{PA}$ & NS & NS & NS & 0.10 & 0.12 & NS & 0.14 & 0.13 \\
\hline \multirow[t]{2}{*}{ Ca alone } & vs. $\mathrm{PA}+\mathrm{Ca}$ & NS & NS & NS & 0.08 & NS & 0.19 & NS & NS \\
\hline & vs. $\mathrm{Ca}+\mathrm{PA}$ & NS & NS & NS & NS & NS & NS & NS & 0.08 \\
\hline $\mathrm{PUT}+\mathrm{Ca}$ & vs. Ca + PUT & NS & NS & NS & 0.06 & 0.17 & NS & 0.16 & 0.10 \\
\hline $\mathrm{SPD}+\mathrm{Ca}$ & vs. $\mathrm{Ca}+\mathrm{SPD}$ & NS & NS & NS & NS & NS & NS & NS & NS \\
\hline
\end{tabular}

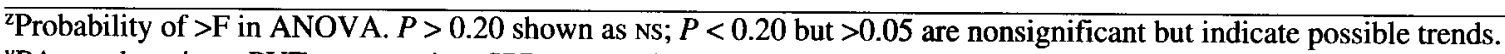
yPA $=$ polyamines; $\mathrm{PUT}=$ putrescine $; \mathrm{SPD}=$ spcrmidine.

${ }^{x} \mathrm{FMAX}=$ maximum force required to penetrate or compress the flesh; FFRC = force at the first peak or at initial flesh failure; FFUL $=$ force at maximum penetration or compression; M@05 = slope at 0.05 -mm penetration or compression. 

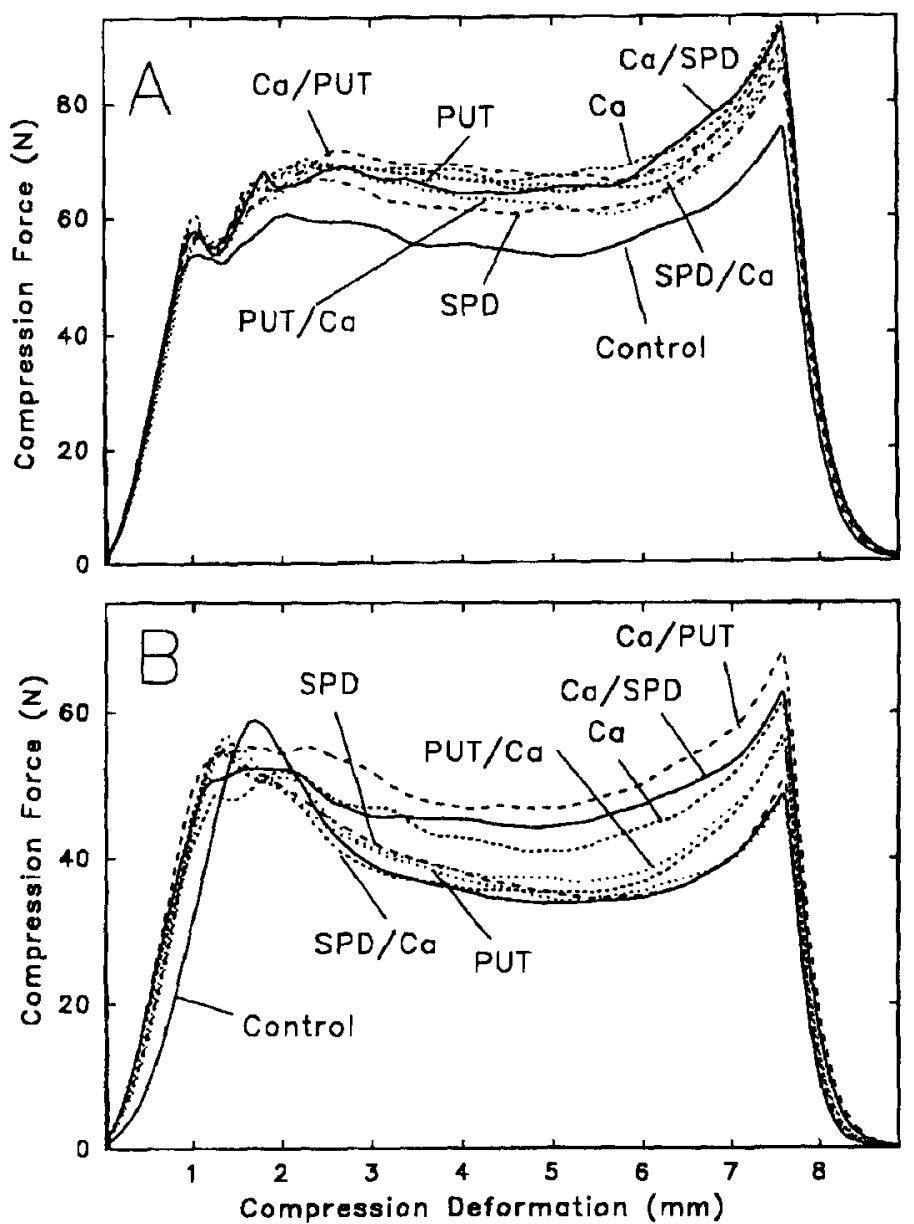

Fig. 3. Texture compression force/deformation curves for 'Golden Delicious' apples after chemical treatment: (A) Before storage and (B) after 24 weeks of storage at $0 \mathrm{C}$. See Fig. 1 for concentrations used.

Tissue compression. The control fruit had significantly lower force values than those in other treatments immediately after infiltration (Fig. 3A, Table 1). However, slopes did not differ among treatments. After 24 weeks (Fig. 3B), the slope of the control fruit was lower than slopes for the other treatments, indicating that the flesh of the controls was more elastic or less rigid, as was shown by the MT test. Although the mean tissue compression curves after 24 weeks of storage appear to differ in height, the differences in FMAX and FFUL among treatments were not significant because of high variability among the samples. Nevertheless, because FFRC of the controls was as high as those of treatments 4,7 , and 8 , and the forces beyond fracture were much lower, we suspect that at least some of the control fruit were crisper and more tender than those of treatments 4, 7, and 8 . Although the differences were not statistically significant, the treatments receiving $\mathrm{Ca}$ alone or first had generally higher FFUL values and higher forces near mid-curve than apples in the other treatments. The effect of $\mathrm{Ca}$ on firmness has been demonstrated in other studies (Sams et al., 1993).

\section{Cell wall calcium concentration}

Pressure infiltration of 'Golden Delicious' apples with 3\% Ca greatly increased the $\mathrm{Ca}$ concentration in cell walls (Table 2). A similar increase in $\mathrm{Ca}$ concentration also was observed when $\mathrm{Ca}$ was the first ion infiltrated; however, this increase was diminished greatly when the $\mathrm{Ca}$ was applied after the polyamines. Treatments with only polyamines did not affect cell wall $\mathrm{Ca}$ concentration of the fruit during the 24 weeks of storage at $0 \mathrm{C}$.
Table 2. Cell wall Ca concentrations ( $\mu \mathrm{g} \cdot \mathrm{g}^{-1}$ dry weight) in 'Golden Delicious' apples during storage at $0 \mathrm{C}$ after treatment with putrescine (PUT), spermidine (SPD), and/or calcium (Ca) in the sequence indicated.

\begin{tabular}{lcccc}
\hline & \multicolumn{4}{c}{ Storage at 0C (weeks) } \\
\cline { 2 - 5 } Chemical (concn.) & 0 & 8 & 16 & 24 \\
\hline Control & $825 \pm 9$ & $744 \pm 13$ & $1049 \pm 19$ & $1213 \pm 126$ \\
PUT (10 mM) & $883 \pm 1$ & $859 \pm 11$ & $828 \pm 16$ & $1221 \pm 38$ \\
SPD (0.5 mM) & $765 \pm 6$ & $863 \pm 50$ & $868 \pm 13$ & $1321 \pm 65$ \\
Ca (3\%) & $3675 \pm 75$ & $3995 \pm 83$ & $5852 \pm 26$ & $5453 \pm 150$ \\
PUT (10 mM)+ & & & & \\
Ca (3\%) & $1618 \pm 9$ & $1594 \pm 19$ & $2434 \pm 21$ & $2213 \pm 45$ \\
SPD (0.5 mM)+ & & & & \\
Ca (3\%) & $1996 \pm 31$ & $1867 \pm 17$ & $2865 \pm 7$ & $2052 \pm 33$ \\
Ca (3\%)+ & & & & \\
PUT (10 mM) & $3707 \pm 23$ & $4400 \pm 53$ & $4870 \pm 157$ & $5824 \pm 67$ \\
Ca (3\%)+ & & & & \\
SPD (0.5 mM) & $4211 \pm 16$ & $2977 \pm 20$ & $4059 \pm 39$ & $5127 \pm 42$ \\
\hline
\end{tabular}

\section{Cell wall polyamine concentrations}

An immediate increase in the concentrations of PUT or SPD in the cell wall was observed when these polyamines were pressureinfiltrated alone or were the first ions to be infiltrated (Figs. 4 and 5). These high concentrations declined rapidly and dropped to a level similar to that of the control by the 16th week of storage. Treatment with $10 \mathrm{~mm}$ PUT led to increases in SPD and spermine (SPN) at week 8 and treatment with $0.5 \mathrm{~mm} \mathrm{SPD}$ also induced an
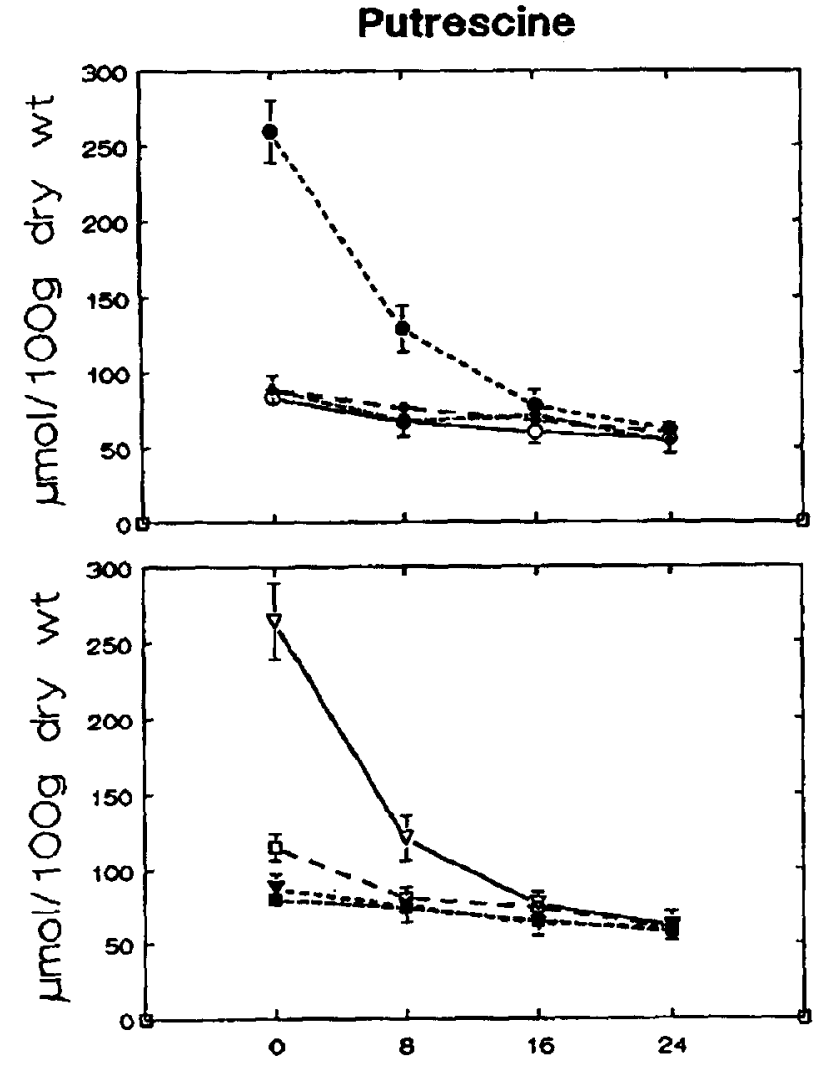

Storage Time (Weeks)

Fig. 4. Cell wall-bound putrescine in 'Golden Delicious' apples. Fruit were pressure-infiltrated with water (open circle); $10 \mathrm{~mm}$ PUT (solid circle); $0.5 \mathrm{~mm}$ SPD (open diamond); $3 \% \mathrm{Ca}$ (solid diamond); $10 \mathrm{~mm}$ PUT followed by 3\% $\mathrm{Ca}$ (open triangle); $0.5 \mathrm{~mm}$ SPD followed by $3 \% \mathrm{Ca}$ (solid triangle); $3 \% \mathrm{Ca}$ followed by 10 mM PUT (open square); or 3\% Ca followed by $0.5 \mathrm{~mm}$ SPD (solid square). Vertical bars represent SE. 


\section{Spermidine}
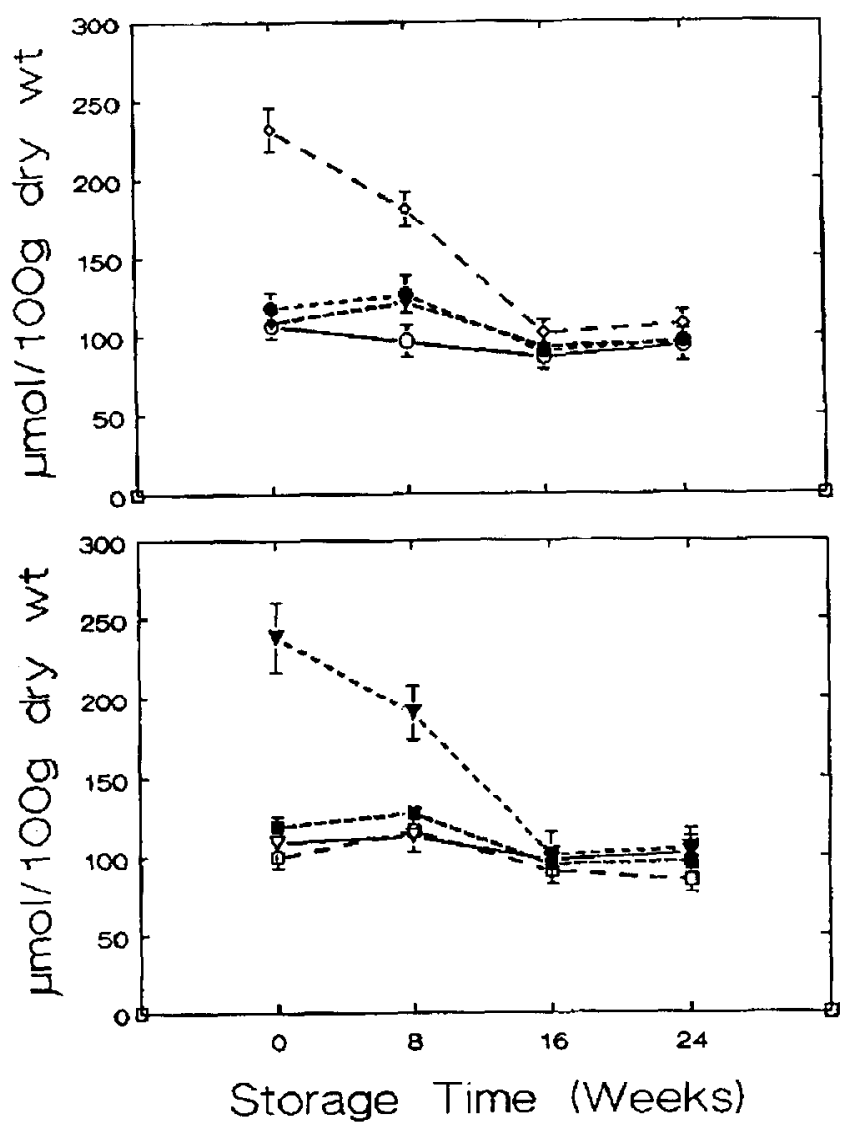

Fig. 5. Cell wall-bound spermidine in 'Golden Delicious' apples. See Fig. 4 for treatment identification. Vertical bars represent SE.

increase in SPN (Figs. 5 and 6). Treatment with 3\% Ca also appeared to increase SPD and SPN at week 8 and SPN at week 16. The fruit cell walls contained much less SPN than PUT or SPD. The level of SPN in the cell wall also declined steadily with time in storage at $0 \mathrm{C}$ (Fig. 6).

\section{Discussion}

Ethylene production of 'Golden Delicious' apples appeared to be inversely related to the concentration of $\mathrm{Ca}$ in the fruit tissue (Fig. 1). When Ca was the only ion applied or was the first ion to be infiltrated, cell wall $\mathrm{Ca}$ concentration increased 4- to 5-fold and ethylene production of the fruit was inhibited greatly. When $\mathrm{Ca}$ was the second ion to be infiltrated, cell wall $\mathrm{Ca}$ concentration showed a 2fold increase and ethylene production was inhibited less. Inhibited ethylene production was considered as one factor contributing to delayed senescence of fruit by Ca (Sams and Conway, 1984).

Contrasting results have been published concerning the effects of polyamines on ethylene production. Pennazio and Roggero $(1989,1990)$ reported that an exogenous supply of polyamines stimulated ethylene evolution from intact soybean (Glycine max L.) leaves and detached tobacco (Nicotiana tabacum L.) leaves. The stimulation resulted from increased accumulation of 1aminocyclopropane-1-carboxylic acid (ACC) and higher ethylene-forming enzyme (EFE, ACC oxidase) activity. However, other reports have shown that polyamines inhibit ethylene biosynthesis in fruit tissue (Even-Chen et al., 1982; Hyodo and Tanaka, 1986; Ke and Romani, 1988). In our experiment, polyamines had no apparent effect on ethylene production (Fig. 1). Polyamine-
Spermine
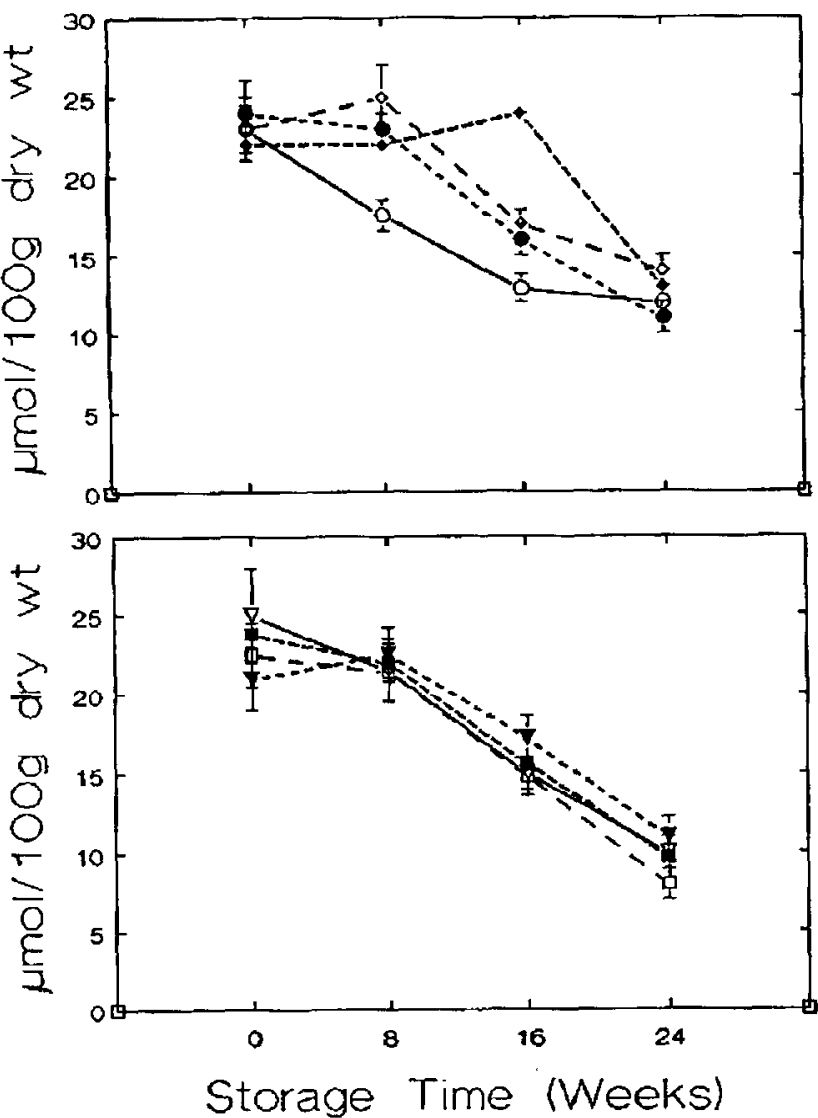

Fig. 6. Cell wall-bound spermine in 'Golden Delicious' apples. See Fig. 4 for treatment identification. Vertical bars represent $\mathrm{SE}$.

treated fruit exhibited a typical climacteric rise in ethylene production at 20C, similar to that of the control fruit. Explaining the discrepancies among the results from various studies is difficult. The relationship and interaction between polyamines and ethylene is not fully understood. Because both polyamines and ethylene are derived from the same precursor, $S$ - adenosylmethionine (SAM), and their biosyntheses yield a common byproduct, 5'-methylthioadenosine (MTA), polyamines and ethylene may interfere with the production and function of one another (Flores et al., 1990). The degree of interference may vary with species, type of tissue, and the experimental systems used.

The initial slopes in the IMT curves were much higher in all the treated fruit than in the control fruit after 24 weeks of storage at 0C (Fig. 2). This result indicates that the control fruit deformed to a greater extent than the treated fruit before actual penetration of the probe; i.e., they were more spongy. These control fruit also were more elastic than the fruit infiltrated with ions (Fig. 3). These data indicate that the texture of the control fruit was the softest among all the treatments. In contrast, treatments $7(\mathrm{Ca}+\mathrm{PUT})$ and $8(\mathrm{Ca}$ + SPD) were the firmest, indicating that there may be an additive beneficial effect of combined polyamine and $\mathrm{Ca}$ treatments on apple firmness.

The relative effectiveness of polyamines in retarding senescence of plant tissues is thought to be related to the number of positive charges per molecule (Galston and Kaur-Sawhney, 1987). Because of its tetramine structure, SPN should have a higher potential for maintaining fruit quality than does SPD (triamine) or PUT (diamine); however, SPN was highly phytotoxic to the apple skin in our previous study (Kramer et al., 1991), and was not included in this study. 
In the treatments where polyamines and $\mathrm{Ca}$ were applied, the amount of each ion bound by fruit cell walls depended on the order in which the ions were infiltrated. When $\mathrm{Ca}$ was applied before PUT or SPD, the concentration of $\mathrm{Ca}$ in the cell wall increased markedly and was similar to the treatment with $\mathrm{Ca}$ alone (Table 1). When Ca was applied as a second ion after PUT or SPD, however, the increase in the concentration of $\mathrm{Ca}$ in the cell wall was reduced greatly. Similar situations occurred for the concentrations of PUT and SPD, depending on the order in which they were infiltrated. This phenomenon indicates that polyamines and $\mathrm{Ca}$ may be competing for the same binding sites in the cell wall. The binding sites could be occupied by whichever ion comes first.

\section{Literature Cited}

Abbott, J.A., D.R. Massie, and A.E. Watada. 1982. The use of a computer with an Instron for textural measurements. J. Text. Stud. 13:413-422.

Abbott, J.A., A.E. Watada, and D.R. Massie. 1984. Sensory and instrument measurement of apple texture. J. Amer. Soc. Hort. Sci. 109:221228.

Altman, A., R. Kaur-Sawhney, and A.W. Galston. 1977. Stabilization of oat leaf protoplast through polyamine mediated inhibition of senescence. Plant Physiol. 60:570-574.

Conway, W.S., C.E. Sams, J.A. Abbott, and B.D. Bruton. 1991. Postharvest calcium treatment of apple fruit to provide broad-spectrum protection against postharvest pathogens. Plant Dis. 75:620-622.

Even-Chen, Z., A.K. Mattoo, and R. Goren. 1982. Inhibition of ethylene biosynthesis by aminoethoxyvinylglycine and by polyamines shunts label from 3,4- $\left[{ }^{14} \mathrm{C}\right]$ methionine into spermidine in aged orange peel discs. Plant Physiol. 69:385-388.

Flores, H.E., R.N. Arteca, and J.C. Shannon. 1990. Polyamines and ethylene: Biochemistry, physiology, and interactions. Amer. Soc. Plant Physiol., Rockville, Md.

Flores, H.E., N.D. Young, and A.W. Galston. 1985. Polyamine metabolism and plant stress, p. 93-114. In: J.L. Key and T. Kosuge (eds.). Cellular and molecular biology of plant stress. Liss, New York.

Galston, A.W. 1983. Polyamines as modulators of plant development. Bioscience 33:382-387.

Galston, A.W. and R. Kaur-Sawhney. 1987. Polyamines and senescence in plants, p. 167-181. In: W.W. Thomson, E.A. Nothnagel, and R.C. Huffaker (eds.). Plant senescence: Its biochemistry and physiology, Amer. Soc. Plant Physiol., Rockville, Md.

Huber, D.J. 1991. Acidified phenol alters tomato cell wall pectin solubility and calcium content. Phytochemistry 30:2523-2527.

Hyodo, H. and K. Tanaka. 1986. Inhibition of 1-aminocyclopropane-1carboxylic acid synthase activity by polyamines, their related com- pounds and metabolites of $S$-adenosylmethionine. Plant Cell Physiol. 27:391-398.

Kaur-Sawhney, R. and A.W. Galston. 1979. Interaction of polyamines and light on biochemical processes involved in leaf senescence. Plant Cell Environ. 2:189-196.

Ke, D. and R.J. Romani. 1988. Effects of spermidine on ethylene production and the senescence of suspension-cultured pear fruit cells. Plant Physiol. Biochem. 26:109-116.

Kramer, G.F., C.Y. Wang, and W.S. Conway. 1989. Correlation of reduced softening and increased polyamine levels during low-oxygen storage of 'McIntosh' apples. J. Amer. Soc. Hort. Sci. 114:942-946.

Kramer, G.F., C.Y. Wang, and W.S. Conway. 1991. Inhibition of softening by polyamine application in 'Golden Delicious' and 'McIntosh' apples. J. Amer. Soc. Hort. Sci. 116:813-817.

Mason, J.L., J.J. Jasmin, and R.L. Granger. 1975. Softening of 'McIntosh' apples reduced by a postharvest dip in calcium chloride solution plus thickeners. HortScience 10:524-525.

Pennazio, S. and P. Roggero. 1989. Stimulation of ethylene production by exogenous spermidine in detached tobacco leaves in the light. Biol. Plant. 31:58-66.

Pennazio, S. and P. Roggero. 1990. Exogenous polyamines stimulate ethylene synthesis by soybean leaf tissues. Ann. Bot. 65:45-50.

Poovaiah, B.W. 1988. Calcium and senescence, p. 369-389. In: L. Nooden and A.C. Leopold (eds.). Senescence and aging in plants. Academic, New York.

Sams, C.E. and W.S. Conway. 1984. Effect of calcium infiltration on ethylene production, respiration rate, soluble polyuronide content, and quality of 'Golden Delicious' apple fruit. J. Amer. Soc. Hort. Sci. 109:53-57.

Sams, C.E., W.S. Conway, J.A. Abbott, R.J. Lewis, and N. Ben-Shalom. 1993. Firmness and decay of apples following postharvest pressure infiltration of calcium and heat treatment. J. Amer. Soc. Hort. Sci. 118:623627.

Sharples, R.O. and D.S. Johnson. 1977. The influence of calcium on senescence changes in apples. Ann. Applied Biol. 85:450-453.

Slocum, R.D. and H.E. Flores. 1991. Biochemistry and physiology of polyamines in plants. CRC Press, Boca Raton, Fla.

Smith, T.A. 1990. Plant polyamines-metabolism and function, p. 1-23. In: H.E. Flores, R.N. Arteca, and J.C. Shannon (eds.). Polyamines and ethylene: Biochemistry, physiology, and interactions. Amer. Soc. Plant Physiol., Rockville, Md.

Tong, C.B.S. and K.C. Gross. 1990. Stimulation of ethylene production by a cell wall component from mature green tomato fruit. Physiol. Plant. 80:500-506.

Watada, A.E. and D.R. Massie. 1981. A compact automatic system for measuring $\mathrm{CO}_{2}$ and $\mathrm{C}_{2} \mathrm{H}_{4}$ evolution by harvested horticultural crops. HortScience 16:39-41. 